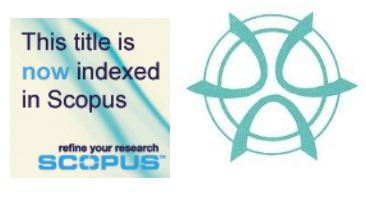

PLANNING MALAYSIA:

Journal of the Malaysian Institute of Planners

VOLUME 19 ISSUE 3 (2021), Page 157 - 168

\title{
ALTERNATIVE NUMERAIRES FOR MEASURING WELFARE CHANGES: REVIEW OF EMPIRICAL ENVIRONMENTAL VALUATION STUDIES
}

\author{
Akhmad Solikin ${ }^{1}$ \\ Accounting Department \\ POLYTECHNIC OF STATE FINANCE STAN, INDONESIA
}

\begin{abstract}
This study examines numeraire or an account unit that measures household welfare changes. Although money metric usually determines budget constraint, textbook explanations of the alternative metrics are limited. Therefore, the study aimed to fill the existing gap by systematically and qualitatively analysing previously published articles on environmental valuation in developing countries. The results showed the existence of alternative numeraires in working time, commodities, and financing. The alternative metrics are useful in the valuation of environmental goods and services in developing countries, especially those involving poor respondents and underdeveloped monetary transactions. The nonmonetary payments reduce zero bids due to the inability of subsistence people to pay in cash and help the poor express their true environmental values.
\end{abstract}

Keywords: numeraire, welfare change, willingness to work, willingness to pay

\footnotetext{
${ }^{1}$ Associate Professor, Polytechnic of State Finance STAN, Ministry of Finance, Indonesia. Email: akhsol@pknstan.ac.id
} 
Akhmad Solikin

Alternative Numeraires for Measuring Welfare Changes: Review of Empirical Environmental Valuation Studies

\section{INTRODUCTION}

Economic valuation of environmental goods and services is important in the policy context when environmental change has economic impact (Söderqvist \& Soutukorva, 2009). Recently, there is a rise of governments' interests to economic value of environmental goods and services in order to measure state wealth (e.g. Solikin et al., 2019). In the case of Indonesia, Ministry of Finance keens to value natural resources in order to put the values in the environmental balance sheet in particular and for optimal fiscal policy in general. In the valuation process, a researcher should make decision on the valuation approach, since different approach has its specific strengths, weaknesses, and challenges. One of challenges in the use of contingent valuation method (CVM), an approach capable of estimating nonmarket values (Sunoto et al., 2020), is to choose appropriate valuation yardstick or numeraire. The yardstick is usually measured in monetary, while other measures are increasingly popular among researchers.

\section{RESEARCH BACKGROUND}

Standard introduction to economics and microeconomics textbooks describes price and quantity in vertical and horizontal axes when depicting demand and supply graphs. However, it least discusses the need to use alternatives other than monetary to analyze demand and supply. There are discussions on numeraire in the intermediate microeconomics textbook, such as Varian (2010). The numeraire measures other prices or income and helps avoid redundancy. Varian (2010) also illustrated the Robinson Crusoe's economic concept that uses a coconut as a numeraire to measure wage rate. In general, it is essential to find alternative numeraires to measure environmental goods and services in an empirical study. The failure to include such alternative measures may induce bias in the estimated valuation values in developing countries.

\section{LITERATURE REVIEW}

The welfare impact of a proposed program or project could be illustrated in indifference curve changes. Theoretically, the distance among indifference curves illustrates the welfare, utility enhancement, or impairment measured in money or alternative numeraires.

\section{Money Metric}

The money metric is usually used to denote underlying utility changes because they are unobservable. Money is an appropriate welfare measure because it is widely used by people to relate their preferences or utility changes. People buy packages of goods and services using money in the transactions. Additionally, money easily aggregates and is readily retransformed to goods and services as sources of utilities (Ahlheim et al., 2010). 
PLANNING MALAYSIA

Journal of the Malaysia Institute of Planners (2021)

\section{Arguments for Alternative Numeraires}

Researchers do not need to confine matching welfare change with monetary measures (Carson and Louviere, 2011) for various reasons. First, the respondents are poor so using monetary payment will limit the monetary payment (willingness to pay, WTP) they offer (Nath et al., 2017). Since poor people in developing countries (Whittington, 2010) have a limited budget, they elicit zero or near zero WTPs when asked about money, though they value environmental goods and services. In Lower Kinabatangan, Sabah, almost half of the respondents are unwilling to pay for various reasons, with $7 \%$ stating they did not spare income to pay (Latip et al., 2013).

Second, using non-monetary payment (willingness to work, WTW) instead of WTP increases participation rate or decreases the zero bids. The planned program may need local participation, which could be achieved by creating an unpaid working day (Arbiol et al., 2013; Casiwan-Launio et al., 2011; Schiappacasse et al., 2013). In this regard, further inquiry of valid zero bids due to inabilities to pay showed that most respondents were willing to pay through non-monetary transactions (Brouwer et al., 2008).

Third, the market in the region is not well developed, as shown by barter transactions or partial subsidies (Saizan et al., 2019). There are pervasive in-kind payments for community activities (Diafas et al., 2017). This is in line with Gorkhali (2009) that stated the Nepal remote area is characterized by low ability to pay, a barter economy, less cash in the market, and typical labor as a community's input to a project; making non-monetary contributions appealing. However, the imperfect market economy may produce a downward bias on implementing the WTP. Fourth, the mean WTW is more stable than WTP (Jiang, 2018; Pondorfer \& Rehdanz, 2018). Fifth, WTP may yield a lower estimate due to institutional distrust in corruption-prone countries (Kassahun et al., 2020).

Disagreement exists in using non-monetary contributions because, as a numeraire, the labour is not easily convertible to utility (Ahlheim et al., 2010). The numeraire must have four characteristics: (1) to fulfil theoretical requirements, it must be strictly monotonically increasing in individual utility, (2) to satisfy the psychological criterion of relating the numeraire with utility, it must be extensively used in everyday life, (3) it must be easily aggregated across people, and (4) it must be easily converted to money (Ahlheim et al., 2010). However, Vondolia et al. (2014) argue that the choice of numeraire does not responsible for the results; rather respondents' acquaintance with the numeraires that matters. If respondents are familiar with the numeraires then the results should be indifferent between money and other measures. Additionally, eliciting cash WTP could be biased when the existing arrangement does not contain money expenditures (Abramson et al., 2011). 
Akhmad Solikin

Alternative Numeraires for Measuring Welfare Changes: Review of Empirical Environmental Valuation Studies

\section{RESEARCH METHOD}

This study answers the research question using a literature review from the internet, comprising articles that cite and appear in reference lists of nonmonetary vehicles as numeraire (van Houtven et al., 2017). It only reviews the valuation of environmental goods and services. Additionally, articles written in languages other than English, Bahasa Indonesia, and Malay are excluded due to the language barrier.

Five topics are specifically sought after in the literature, including: (1) whether the literature includes theoretical exposition; (2) the majority of payment vehicles used in the studies; (3) determinants of WTW; (4) how to translate nonmonetary to monetary values; and (5) whether the non-monetary value significantly differs from the monetary valuation. To compute mean WTW in hours per month, this article assumes 8 hours per day, 30 days per month, four weeks per month, and 365 days per year.

\section{RESULTS AND DISCUSSION Theoretical Exposition}

Most of the reviewed literature did not offer theoretical discussion but focused on empirical estimation (Das and Mahanta, 2013; Girma and Beyene, 2012). Jiang (2018), Saizan, et al. (2019) only discussed why the willingness to contribute (WTC) or WTW is more suitable than WTP. Similarly, Ishiguro (2019) did not discuss the theory but directed interested readers towards the public goods model, proving that people could substitute money and time in producing public goods.

Arbiol et al. (2013) follows Eom and Larson (2006), which used compensating surplus measures of WTP, though modified to incorporate time budget. The indirect utility function (V) could be represented as:

$$
V\left(M-W T C^{L}, Z, q^{1}\right)=V\left(M, Z, q^{0}\right)
$$

where $M$ is time budget, $W T C^{L}$ is the willingness to contribute labor, $Z$ is the vector of socioeconomic variables, $q^{0}$ is the condition before the intervention, and $q^{l}$ is the condition after the program. Therefore, WTC $C^{L}$ represents WTW for environmental improvements $\left(q^{l}-q^{0}\right)$. The model could be further made empirical by considering the formats used to elicit WTP or WTW. Susilo et al. (2017) also used this framework to value mangrove restoration in Mahakam Delta, Indonesia. Alternatively, the standard individual preference function (Haab \& McConnell, 2002) states that respondents gain utilities from the bundle of private and public goods. To measure WTW, WTP is substituted with WTW and budget constraint with time constraint (Arbiol et al., 2013; Gibson et al., 2016; Navrud \& Vondolia, 2020; Solikin, 2017). 
PLANNING MALAYSIA

Journal of the Malaysia Institute of Planners (2021)

\section{Alternative Payment Vehicles}

Many authors empirically used non-monetary payments, the most popular choice being labor time or WTW (Abramson et al., 2011; Alam, 2013; Arbiol et al., 2013; Casiwan-Launio, Shinbo \& Morooka, 2011; Das \& Mahanta, 2013; Gibson et al., 2016; Girma \& Beyene, 2012; Gorkhali, 2009; Hung, Loomis \& Thinh, 2007; Ishigu, 2019; Ninan \& Sathyapalan, 2005; Notaro \& Paletto, 2011; Saizan et al., 2019; Saxena, Bisht, \& Singh, 2008; Schiappacasse et al., 2013; Solikin, 2017; Tilahun et al., 2015; Vasquez, 2014; \& Vondolia et al., 2014). In contrast, the less popular alternatives include commodity or harvest, such as rice (Navrud $\&$ Vondolia, 2020), providing meals (Diafas et al., 2017), borrowing (Abramson et al., 2011), and income tax and reduction of government subsidy for groceries (Hassan et al., 2018).

Several studies used voluntary working to predict WTP time, WTW, or WTC. For instance, Hung, Loomis, and Thinh (2007) used unpaid work from 0 to 30 days per year to value a forest fire prevention program in Vietnam. Furthermore, Saxena, Bisht, and Singh (2008) used WTW and WTP to lowincome groups in three villages in India to value gazelle habitat. Similarly, Abramson et al. (2011) used WTP, WTW, and borrowing or interest-free loans to potable water programs in Zambia. The results showed that WTW is the highest, WTP is the lowest, while borrowing lies between labor and cash amounts. Schiappacasse et al. (2013) used money and time variables to value a forest restoration project in Chile. Similarly, Alam (2013) used the money and time variables to value the restoration of a river ecosystem in Bangladesh. In contrast, Arbiol et al. (2013) used labor as a numeraire to value leptospirosis prevention in Metro Manila, Philippines. Solikin (2017) used the money and unpaid working days variables to value Indonesia's deforestation and forest degradation avoidance. Similarly, Vasquez (2014) used money and labor to value improved water services in Guatemala. Moreover, Navrud and Vondolia (2020) used money, labor time, and harvest contributions to value flood risk prevention in Ghana.

Critics state that the elicited WTW depends on the tasks offered to the respondents. Specifically, the measure of contribution in labor may not be appropriate for all programs (Rai and Scarborough, 2015). According to the critics, the tasks asked in WTW studies should be designed to suit the valuation project. For instance, voluntary work could comprise tree planting, forest management, or the number of days refraining from logging (Ishiguro, 2019). Voluntary work could also encompass environmental clean-ups and health advocacy activities (Saizan et al., 2019), labor-meal, or providing meals for workers participating in the village development program (Diafas et al., 2017). People could also voluntarily plant seedlings, monitor their growth, and protect mangrove areas (Susilo et al., 2017). 
Akhmad Solikin

Alternative Numeraires for Measuring Welfare Changes: Review of Empirical Environmental Valuation Studies

\section{Determinants of WTW and Other Numeraires}

Several socioeconomic variables are usually included in the regression models, such as gender, age, education, household size, income, and occupation. Table 1 shows the information on the significance and the direction between independent and dependent variables.

In most cases, in addition to socioeconomic variables, other specific variables pertinent to the research are also included. They include landholding size (Das \& Mahanta, 2013; Girma \& Beyene, 2012; Schiappacasse et al., 2013), village-type (Das \& Mahanta, 2013), house type (Jiang, 2018), ethnicity (Girma $\&$ Beyene, 2012), length of stay (Girma \& Beyene, 2012; O'Garra, 2009; Solikin, 2017) and type of forest use (Ishiguro, 2019). As a result, the WTP and WTW determinants could be different (Solikin, 2017) or similar (Dai et al., 2017).

Several conclusions could be inferred from Table 1. First, males are willing to contribute labor because they are associated with fieldwork. Second, age negatively affects WTW since older people may not be fit for the hard work program. Third, education negatively affects WTW, as seen when respondents with better education have better jobs, making them reluctant to work in the fields or forests. Fourth, the effect of income on WTW is inconclusive, as seen in the reluctance to work in the field for negative effects and increased volunteering related to nature for positive effects. Fifth, household size positively affects WTW by increasing potential labor in fieldwork.

Table 1. Determinants of WTW for Selected Articles

\begin{tabular}{|l|l|l|}
\hline \multicolumn{1}{|c|}{ Variable } & \multicolumn{1}{|c|}{ Significant } & \multicolumn{1}{c|}{ Insignificant } \\
\hline $\begin{array}{l}\text { Gender } \\
\text { male=1 })\end{array}$ & $\begin{array}{l}\text { + Casiwan-Launio et al. (2011); Dai et al. } \\
\text { (2017); Das \& Mahanta (2013); Ishiguro } \\
\text { (2019); O'Garra (2009) }\end{array}$ & $\begin{array}{l}\text { Arbiol et al. (2013); Solikin } \\
\text { (2017); Susilo et al. (2017) }\end{array}$ \\
\hline Age & $\begin{array}{l}\text { - Casiwan-Launio et al. (2011); Das \& } \\
\text { Schiappacasse et al. (2013) }\end{array}$ & $\begin{array}{l}\text { Arbiol et al. (2013); Girma \& } \\
\text { Beyene (2012); O'Garra (2009); } \\
\text { Solikin (2017); Susilo et al. } \\
\text { (2017) }\end{array}$ \\
\hline $\begin{array}{l}\text { Literacy/ } \\
\text { Education }\end{array}$ & $\begin{array}{l}\text { - Dai et al. (2017); Das \& Mahanta } \\
\text { (2013); Ishiguro (2019) }\end{array}$ & $\begin{array}{l}\text { Girma \& Beyene (2012); O'Garra } \\
\text { (2009); Susilo et al. (2017) }\end{array}$ \\
\hline $\begin{array}{l}\text { Household } \\
\text { size }\end{array}$ & $\begin{array}{l}\text { + Ishiguro (2019); O'Garra (2009); - } \\
\text { Susilo et al. (2017) }\end{array}$ & $\begin{array}{l}\text { Das \& Mahanta (2013); Girma \& } \\
\text { Beyene (2012) }\end{array}$ \\
\hline $\begin{array}{l}\text { Income } \\
\text { - Ishiguro (2019), Susilo et al. (2017); + } \\
\text { Casiwan-Launio et al. (2011); } \\
\text { Schiappacasse et al. (2013) }\end{array}$ & $\begin{array}{l}\text { Arbiol et al. (2013); O'Garra } \\
\text { (2009) }\end{array}$ \\
\hline $\begin{array}{l}\text { Occupation } \\
\text { Knowledge/ } \\
\text { participation/ } \\
\text { attitude }\end{array}$ & $\begin{array}{l}\text { Ishiguro (2019) } \\
\text { Al. (2011); Dai et al. (2017); Girma \& } \\
\text { Beyene (2012); O'Garra (2009); } \\
\text { Schiappacasse et al. (2013); Solikin } \\
\text { (2017); Susilo et al. (2017) }\end{array}$ & $\begin{array}{l}\text { Dai et al. (2017); Das \& Mahanta } \\
\text { (2013); Susilo et al. (2017); } \\
\text { O'Garra (2009) }\end{array}$ \\
\hline
\end{tabular}


PLANNING MALAYSIA

Journal of the Malaysia Institute of Planners (2021)

\section{Translation to Monetary Value}

The WTW should be converted to monetary to be compared with WTP. When translating WTW to monetary, it is compulsory to consider the working or leisure time and the rate at which value is assigned to the time. When the WTP-labour is assumed to be traded-off with working time, converting person-days to monetary value involves multiplying the mean or median workday by the daily income (Tilahun et al., 2015), official minimum wage (Saxena, Bisht, \& Singh, 2008; Susilo et al., 2017; Vondolia et al., 2014), market wage (Arbiol et al., 2013; Vondolia et al., 2014), or respondents' expected wage (Susilo et al., 2017). Furthermore, estimating the total WTP from households' WTW involves multiplying the daily or minimum wage or other rates by the mean WTW. The result is extrapolated to the number of households in the research area and adjusted with the percentage of respondents willing to contribute.

When the time contribution is assumed to come from leisure time, onethird of the wage is implemented (Arbiol et al., 2013; Casiwan-Launio et al., 2011; O'Garra, 2009; Saizan et al., 2019; Saxena, Bisht, \& Singh, 2008). In this case, the wage rate represents the working contribution trade-off, while one-third of the wage represents the leisure contribution trade-off. Similarly, Schiappacasse et al. (2013) allocated different values of time to respondents that could take the working time voluntarily (using wage rate) and respondents that could not choose freely (using one-third of the wage rate).

Instead of using income or official wage, Gibson et al. (2016) and Solikin (2017) used wage rates from job vacancies in the villages because an official minimum wage for formal employment is substantially lower. However, this is not always the case. For instance, Abramson et al. (2011) found that official minimum wages were 4 to 12 times higher than local wage rates for unskilled labor in Zambia. Recent study by Hagedoorn et al. (2020) suggest of using individual conversion to accommodate heterogeneity in value of time. They argue that using generic wage rate may yield downward bias of the WTP.

\section{Sum of Money vs. Nonmonetary}

Previous literature found that WTW is significantly greater than WTP. The reason for a bigger WTP value may be due to low time value or hypothetical bias (Eom and Larson, 2006). Casiwan-Launio et al. (2011) and Gibson et al. (2016) suggested two reasons for the discrepancies. First, a missing or incomplete labor market lowers opportunity costs of time, as previously mentioned by Eom ad Larson (2006). For instance, transportation is very difficult in the Philippines in the rainy season, hampering workers' mobility to get jobs outside the area. Second, sacrifice of potential income (as in case of WTW) is psychologically less painful compared to surrendering hard earned income (as in case of WTP). The second reason is reinforced by the social norms where labour contribution to community program indicates being a good village resident. However, as 
Akhmad Solikin

Alternative Numeraires for Measuring Welfare Changes: Review of Empirical Environmental Valuation Studies

previously mentioned, the difference between WTW and WTP diminishes when respondents are familiar with the non-monetary payment (Vondolia et al., 2014). For instance, Diafas et al. (2017) found no significant difference between WTP and WTW in Kenya due to respondents' familiarity with both payment vehicles. Similarly, Gibson et al. (2016) found the same result due to the functioning labor market in the villages surrounding Cambodia's capital city.

Several studies showed higher WTW than WTP, including Gorkhali (2009), which found that WTW was 2.6 to 4.8 times higher than WTP for quality improvement of a hydropower project in Nepal. The discrepancy is more considerable in the most remote areas, where the WTW is 9.4 times higher compared to WTP. Furthermore, Saxena, Bisht, and Singh (2008) showed that the WTW value was more than four times WTP in India. Schiappacasse et al. (2013) found that WTW was almost seven times greater than the WTP in reforestation in Chile. According to Solikin (2017), villagers in Berau District, Indonesia elicited WTW 8.5 times higher than WTP in valuing deforestation and forest degradation avoidance. Similarly, Casiwan-Launio et al. (2011) showed that the WTW is 3 or 8 times greater than the WTP in a marine reserve in the Philippines.

Exceptions for this general trend include Vondolia et al. (2014), which found that mean WTP is 2.32 higher than mean WTW. This is possible when WTW is converted to WTP using the minimum wage. Additionally, Navrud and Vondolia (2020) found that the probability of farmers purchasing flood risk insurance is higher when premium as monetary and harvest rather than as labor. O'Garra (2009) also found higher WTP compared to WTC labor in Fiji probably due to outlier data.

The percentage of respondents that answered "yes" to participate in non-monetary contribution implies the suitability of the non-monetary measures. Regarding this, Dai et al. (2017) found that $73.57 \%$ of respondents were willing to contribute labor, while $55.65 \%$ were willing to contribute financially. Moreover, Ishiguro (2019) showed percentages of respondents willing to participate in voluntary works in several villages in Cambodia. The study showed that $78 \%$ of respondents were willing to participate in forest preservation two days per year, $44 \%$ in forest management one day every two years, and $57 \%$ refraining from logging three days each month. Furthermore, Nath et al. (2017) showed that $85 \%$ of respondents in Kuala Selangor, Malaysia are willing to contribute non-monetary through an awareness program, (82\%) tree planting, $75 \%$ patrolling, and fire protection, and $74 \%$ community-based forest management. Ahlheim et al. (2010) valued a landslide protection program in Vietnam and found that more than $85 \%$ of respondents stated their WTW and WTP.

Recalculating mean WTW based on hours per month found that they range from 3.83 (Navrud \& Vondolia, 2019) to 31.40 (Dai et al., 2017). Saizan et 
PLANNING MALAYSIA

Journal of the Malaysia Institute of Planners (2021)

al. (2019) found that respondents are willing to pay an average of 6.68 hours per month for leptospirosis prevention in Malaysia. Moreover, Das and Mahanta (2013) found that respondents living in forest villages were willing to contribute 12 to 16 hours for biodiversity conservation in Assam, India. According to Solikin (2017), the mean number of days a respondent is willing to contribute to the program is 13.50 hours. Saxena, Bisht, and Singh (2008) valued the habitat function of planted forests in India and found that the WTW average is 11.18 hours. Furthermore, Arbiol et al. (2013) found that the WTW average was 10.66 hours per month in valuing leptospirosis prevention projects in Manila, The Philippines. The results show that mean WTW varies with study location, goods and services in questions, and the study design. Therefore, further research should carefully design the study to suit the proposed program.

\section{CONCLUSION}

In the valuation of environmental goods and services, especially when using the contingent valuation method, the use of monetary or nonmonetary measures determines the estimate of welfare change. When majority of local people are very poor, the money market is underdeveloped, barter is prevalent, contribution in kind is a social norm, and then using money to value WTP is inappropriate. An alternative to monetary payment is voluntary working (WTW) or contributing commodity.

This study reviewed the use of non-monetary contribution, resulting in five conclusions. First, most WTW studies do not expose theoretical foundations. Most studies use standard individual preference theory amended using time constraint and bundles of public rather than budget constraint and all private goods, respectively. Second, the most popular alternative measure is voluntary working that suits the program evaluated, while the less common alternatives are a commodity, providing a meal, or credit. Third, WTW determinants include age, income, gender, household size, education, knowledge or attitude, and variables suitable to the project designs evaluated. Fourth, in translating the WTW to WTP, researchers usually use wage rate for trade-off between contribution-working or one-third of the wage rate if assumed that trade-off is between contributionleisure. Recent study, however, calls for conversion rate which accommodate individual heterogeneity. Fifth, the WTW is generally larger than WTP due to low leisure time value in the villages or remote areas, as indicated by limited job opportunities or difficult transportation.

Future studies should examine the theoretical basis for using WTW. In addition, future empirical research on environmental valuation should seriously consider using WTW in addition to standard WTP. Determinants of WTW included in the empirical studies should also consider different nature of WTW and WTP. 
Akhmad Solikin

Alternative Numeraires for Measuring Welfare Changes: Review of Empirical Environmental Valuation Studies

\section{REFERENCES}

Abramson, A., Becker, N., Garb, Y., \& Lazarovitch, N. (2011). Willingness to pay, borrow and work for rural water service improvements in developing countries. Water Resources Research, 47, W11512.

Ahlheim, M., Frör, O., Heinke, A., Duc, N. M., \& Dinh, P. V. (2010). Labour as a utility measure in contingent valuation studies: How good is it really? FZID Discussion Paper No. 13-2010. Stuttgart, Germany: Center for Research on Innovation and Services, University of Hohenheim.

Alam, K. (2013). Factors affecting public participation in river ecosystem restoration: Using the contingent valuation method. The Journal of Developing Areas, 47(1), 223-240.

Arbiol, J., Borja, M., Yabe, M., Nomura, H., Gloriani, N. \& Yoshida, S. (2013). Valuing human leptospirosis prevention using the opportunity cost of labor. International Journal of Environmental Research and Public Health, 10, 1845-1860.

Brouwer, R., Akter, S., Brander, L., \& Haque, E. (2008). Economic valuation of flood risk exposure and reduction in a severely flood-prone developing country. Environment and Development Economics, 14, 397-417.

Carson, R. T. \& Louviere, J. L. (2011). A common nomenclature for stated preference elicitation approaches. Environmental and Resource Economics, 49(4), 539-559.

Casiwan-Launio, C., Shinbo, T., \& Morooka, Y. (2011). Island villagers' willingness to pay for the sustainability of a marine fishery reserve: Case of San Miguel Island, Philippines. Coastal Management, 39, 459-477.

Dai, H., Lee, C., Cheng, K. \& Zong, C. (2017). Community residents' willingness to contribute to wetland ecosystem services in Sanjiang Plain Natural Reserves. Journal of Natural Resources, 32(6), 977-987.

Das, D. \& Mahanta, R. (2013). Willingness to spend labor hour for biodiversity conservation: A case study with special reference to village forest dwellers and encroachers in Assam. Journal of Biodiversity, 4(1), 45-51.

Diafas, I., Barkmann, J. \& Mburu, J. (2017). Measurement of bequest value using a nonmonetary payment in a choice experiment- The case of improving forest ecosystem services for the benefit of local communities in rural Kenya. Ecological Economics, 140, 157-165.

Eom, Y-S. \& Larson, D. M. (2006). Valuing housework time from the willingness to spend time and money for environmental quality improvements. Review of Economics of the Households, 4, 205-227.

Gibson, J. M., Rigby, D., Polya, D. A. \& Russell, N. (2016). Discrete choice experiment in developing countries: Willingness to pay versus willingness to work. Environmental and Resource Economics, 65, 697-721.

Girma, W. \& Beyene, F. (2012). Willingness to contribute to collective forest management: Evidence from Godere in the Gambela Region of Ethiopia. The Journal of Socio-Economics, 41, 79-86.

Gorkhali, S. P. (2009). Economic Analysis of Infrastructure Investments: National Benefits and Local Costs- Case Study of a Hydropower Project in Nepal. Göttingen, Germany: Cuvillier Verlag. 
Haab, T. C. \& McConnell, K. E. (2002). Valuing Environmental and Natural Resources: The Econometrics of Nonmarket Valuation. Cheltenham, UK \& Northampton, MA, USA: Edward Elgar.

Hagedoorn, L. C., Koetse, M. J., van Beukering, P. J. H. \& Brander, L. M. (2020). Time equals money? Valuing ecosystem-based adaptation in a developing country context. Environment and Development Economics, 25, 482-508.

Hassan, S., Olsen, S. B. \& Thorsen, B. J. (2018). Appropriate payment vehicles in stated preference studies in developing economies. Environmental Resource Economics, 71, 1053-1075.

Hung, L. T., Loomis, J. B., \& Thinh, V. T. (2007). Comparing money and labor payment in contingent valuation: The case of forest fire prevention in the Vietnamese context. Journal of International Development, 19, 173-185.

Ishiguro, K. (2019). Evaluation of forest preservation in Cambodian rural villages. Journal of Sustainable Development, 12(1), 27-38.

Jiang, X. (2018). Analyzing the willingness to work and willingness to pay for RWH in Japan. Jurnal Lanskap Indonesia, 10(2), 3-45.

Kassahun, H. T., Jacobsen, J. B. \& Nicholson, C. F. (2020). Revisiting chut and land labor for valuing environmental goods and services in developing countries. Ecological Economics, 177, 106771.

Latip, N. A., Badarulzaman, N., Marzuki, A., \& Umar, M. U. (2013). Sustainable forest management in Lower Kinabatangan, Sabah: Issues and current practices. Planning Malaysia, 11, 59-84.

Nath, T. K., Bin Dahalan, M. P., Parish, F., \& Rengasamy, N. (2017). Local peoples' appreciation on and contribution to the conservation of peatland swamp forests: Experience from Peninsular Malaysia. Wetlands, 37, 1067-1077.

Ninan, K. N. \& Sathyapalan, J. (2005). The economics of biodiversity conservation: A study of the coffee-growing region in the Western Ghats of India. Ecological Economics, 55, 61-72.

Notaro, S. \& Paletto, A. (2011). Links between mountain communities and environmental services in the Italian Alps. Sociologia Ruralis, 51(2), 137-157.

Navrud, S. \& Vondolia, G. K. (2020). Farmers' preferences for reductions in flood risk under monetary and non-monetary payment modes. Water Resources and Economics, 30, 100151.

O'Garra, T. (2009). Bequest values for marine resources: How important for indigenous communities in less-developed economies? Environmental and Resource Economics, 44, 179-202.

Pondorfer, A. \& Rehdanz, K. (2018). Eliciting preferences for public goods in nonmonetized communities: Accounting for preference uncertainty. Land Economics, 94(1), 73-86.

Rai, R. K. \& Scarborough, H. (2015). Nonmarket valuation in developing countries: Incorporating labor contributions in environmental benefits estimates. Australian Journal of Agricultural and Resource Economics, 59, 479-498.

Saizan, S., Sukeri, S., Zahiruddin, W. M., Shafei, M. N., Rukman, A. H., Malina, O., Jamaluddin, T. Z. M. T., \& Aziah, D. (2019). Economic benefit of leptospirosis prevention in Kelatan, Malaysia: Willingness-to-contribute approach. International Journal of Health Planning Management, 34, e817-e823. 
Akhmad Solikin

Alternative Numeraires for Measuring Welfare Changes: Review of Empirical Environmental Valuation Studies

Saxena, A. K., Bisht, N. S., \& Singh, C. J. (2008). The value of the Indian gazelle (Gazella gazelle): A case study in Haryana, India. The Indian Forester, 134(10), 12891295.

Schiappacasse, I., Vasquez, F., Nahuelhual, L., \& Echeverria, C. (2013). Labor as a welfare measure in contingent valuation: The value of a forest restoration project. Ciencia e Investigacion Agraria, 40(1), 69-84.

Söderqvist, T. \& Soutukorva, A. (2009). On how to assess the quality of environmental valuation studies. Journal of Forest Economics, 15, 15-36.

Solikin, A. (2017). Willingness to pay and willingness to work to avoid deforestation and forest degradation. In Taufik, T. et al. (Eds.). ICoSI 2014: Proceeding of the $2^{\text {nd }}$ International Conference on Sustainable Innovation. Singapore: Springer Nature.

Solikin, A., Abdul Rahman, R., Saefrudin, E, Suboh, N., Zahari, N. A. \& Wahyudi, E. (2019). Using travel cost method (TCM) to value forests: Cases of Pahang National Park and Srengseng Jakarta Urban Forests. Planning Malaysia, 17(1), 365-376.

Sunoto, Y. N., Fatiah, A. A., Ponrahono, Z., \& Osman, M. M. (2020). Profiling the perceived mangrove forest use-value and community's willingness to pay for mangrove conservation. Planning Malaysia, 18(3), 229-240.

Susilo, H., Takahashi, Y., \& Yabe, M. (2017). The opportunity cost of labor for valuing mangrove restoration in Mahakam Delta, Indonesia. Sustainability, 9, 2169.

Tilahun, M., Vranken, L., Muys, B., Deckers, J., Gebregziabher, K., Gebrehiwot, K., Bauer, H., \& Mathijs, E. (2015). Rural households' demand for frankincense forest conservation in Tigray, Ethiopia: A contingent valuation analysis. Land Degradation and Development, 26, 642-653.

van Houtven, G. L., Pattanayak, S. K., Usmani, F., \& Yang, J.-C. (2017). What are households' willingness to pay for improved water access? Results from a metaanalysis. Ecological Economics, 136, 126-135.

Varian, H. A. (2010). Intermediate Microeconomics: A Modern Approach, 8th Ed. New York: W.W. Norton.

Vasquez, W. F. (2014). Willingness to pay and willingness to work for improvements of municipal and community-managed water services. Water Resources Research, 50, 8002-8014.

Vondolia, G. K., Eggert, H., Navrud, S., \& Stage, J. (2014). What do respondents bring to contingent valuation? A comparison of monetary and labor payment vehicles. Journal of Environmental Economics and Policy, 3(3), 253-267.

Whittington, D. (2010). What have we learned from 20 years of stated preference research in less-developed countries? Annual Review of Resource Economics, 2, 209-236.

Received: $12^{\text {th }}$ July 2021. Accepted: $23^{\text {rd }}$ Sept 2021 